\title{
Evaluation of Bioactivities of Gouania tiliaefolia Lam., an Indigenous Traditional Medicinal Plant of Bangladesh
}

\author{
Tufael Ahmed ${ }^{1}$, Rifat Khan ${ }^{1}$, Nafisa Tabassum ${ }^{1}$, Fahima Aktar ${ }^{2}$ and \\ Mohammad Kaisarul Islam ${ }^{2}$ \\ ${ }^{1}$ Department of Pharmacy, State University of Bangladesh, 77 Satmasjid Road, Dhanmondi \\ Dhaka-1205, Bangladesh \\ ${ }^{2}$ Department of Pharmaceutical Chemistry, Faculty of Pharmacy, University of Dhaka \\ Dhaka-1000, Bangladesh
}

(Received: April 20, 2019; Accepted: May 20, 2019; Published: July 22, 2019)

\begin{abstract}
The crude methanol extract of Gouania tiliaefolia Lam. was partitioned by the modified Kupchan method and the fractions were evaluated for total phenolic content, antioxidant, cytotoxic, thrombolytic, hypotonic and heat-induced membrane stabilizing activities. The petroleum ether soluble fraction (PESF) and methanol extract (ME) showed the highest phenolic content of $78.30 \pm 1.60 \mathrm{mg}$ and $70.37 \pm 0.84 \mathrm{mg}$, respectively, which were expressed in gallic acid equivalent (GAE). Similar trends were observed in case of anti-oxidant and cytotoxic activities, where the PESF possessed the highest free radical scavenging activity and brine shrimp lethality $\left(\mathrm{IC}_{50}=2.88 \pm 0.02 \mu \mathrm{g} / \mathrm{ml}, \mathrm{LC}_{50}=2.59 \pm 0.14 \mu \mathrm{g} / \mathrm{ml}\right.$ ), followed by $\operatorname{ME}\left(\mathrm{IC}_{50}=4.79 \pm 0.17 \mu \mathrm{g} / \mathrm{ml}, \mathrm{LC}_{50}=3.38 \pm 0.08 \mu \mathrm{g} / \mathrm{ml}\right)$ and $\mathrm{CSF}\left(\mathrm{IC}_{50}=37.51 \pm 0.96 \mu \mathrm{g} / \mathrm{ml}, \mathrm{LC}_{50}=\right.$ $73.55 \pm 0.26 \mu \mathrm{g} / \mathrm{ml})$. In case of assays for thrombolytic and membrane stabilizing activities, all extractives showed insignificant results compared to the respective standards. The crude methanol extract of G. tiliaefolia was used to examine the in-vivo analgesic (central and peripheral), antidiarrheal and antidiabetic activities in Swiss albino mice. In case of castor oil induced diarrhea, the ME gave better reduction of diarrhea by $71.43 \%$ (at $400 \mathrm{mg} / \mathrm{kg}$-body weight) compared to loperamide $(64.29 \%$ ). Antidiabetic activity was evaluated by oral glucose tolerance test and the ME showed $71.42 \%$ and $75.39 \%$ reduction of blood glucose at doses 200 and $400 \mathrm{mg} / \mathrm{kg}$-body weight, respectively when compared with the standard glibenclamide that reduced blood glucose by $66.17 \%$. The central- and peripheral-analgesic activity was evaluated by the tail-flick test and acetic acid induced writhing test, respectively. In both the cases, ME demonstrated dose-dependent analgesic activity compared to the standards.
\end{abstract}

Key words: Gouania tiliaefolia Lam., total phenolic content, antioxidant, cytotoxicity, thrombolytic, antidiarrheal, antidiabetic

\section{Introduction}

Despite the revolution of modern medicine in the twentieth century, it has been estimated that about one-third of the world's population fails to receive affordable medicines. This has led to a surge in the use of traditional (herbal), complementary and alternative medicines in both developed and developing countries (Twarog et al., 2004). In addition, international public health organizations like World Health Organization (WHO) are encouraging the use of traditional medicines due to its wide biological activities, higher safety-profile and lower costs compared to the synthetic drugs (Sharma et al., 2008; Moniruzzaman et al., 2018). Complementary and alternative medicines, as well as herbal medicines contribute a significant role in providing health care along with mainstream allopathic treatment in Bangladesh. Reportedly more than $80 \%$ of the Bangladeshi people use nonallopathic (i.e., Ayurveda, Siddha, Unani and Homoeopathy) medicines for their primary healthcare and herbs constitute a major ingredient of 
these alternative systems of medicine (Kadir et al., 2013). Though people carry an erroneous belief that medications of natural (e.g., herbal) origin are inherently safe and possess lesser side effects (Firenzuoli et al., 2004), natural constituents could be carcinogenic, initiate allergic symptoms, and interfere with drug bioavailability and metabolism etc. inside the body (Firenzuoli et al., 2007), which requires proper investigation, pure compound isolation, characterization and biological evaluation.

Gouania tiliaefolia Lam. (family: Rhamnaceae), locally known as 'Moshkantur' is a native plant of Bangladesh that has been used extensively for various ailments. For example, juice from the crushed leaves has been used orally and topically to alleviate fever and headache (Khatun et al., 2013). Tribal population in the hill tracts of Bandarban and Rangamati, commonly use the paste of whole plant to cover any wounded area and sores (Motaleb et al., 2015; Sarwar et al., 2018). In the Philippines, it is widely used among locals for curing stomach ulcer (Carag et al., 2017).

Despite its wide use, till date no scientific data has yet been published to evaluate its pharmacological properties or to evaluate its toxicity in-vivo. On the other hand, if the medicinal use of this plant is backed by biological study then further research could be carried out in order to isolate and identify the phytochemical(s) responsible for its bioactivity and later be used for at least new drug discovery and development. Therefore, the objective of this current study was to evaluate the traditional medicinal properties of the G. tiliaefolia by conducting both in-vitro and in-vivo biological assays of the methanol extract of thewhole plant and its various organic soluble fractions.

\section{Materials and Methods}

Collection of sample and extraction: Fresh whole plant of G. tiliaefolia was collected from Rangamati district, south-east of Bangladesh during October 2018. The plant was then identified by the taxonomist of Bangladesh National Herbarium, Dhaka, Bangladesh.
After the collection and identification, the plant samples were cleaned, sun dried and ground into coarse powder. Then $400 \mathrm{gm}$ of this powder was soaked in $1600 \mathrm{ml}$ of methanol in an amber bottle. The container was sealed with a cotton plug and kept for 7 days with occasional shaking to facilitate the extraction of phyto-constituents. The whole mixture was filtered by cotton plug followed by Whatman number 1 filter paper. The filtrate was further evaporated to dryness using a rotary evaporator at reduced temperature and pressure. The concentrated gummy mass was transferred to a clean beaker. Different partitions of the crude extract were obtained using the modified Kupchan method (Van Wagenen et al., 1993). For this $5 \mathrm{~g}$ of the crude extract was re-dissolved in $10 \%$ aqueous methanol and extracted consecutively with petroleum ether, chloroform, dichloromethane and water to provide petroleum ether soluble fraction (PESF, gm), dichloromethane soluble fraction (DCMSF, gm) and chloroform soluble fraction (CSF, gm) and aqueous soluble fraction (AQSF, gm).

Drugs and chemicals: Acetic acid, methanol, Tween-80, vincristine sulfate, diclofenac sodium and normal saline were purchased from retail shops. DMSO was collected from Merck specialties, Mumbai. All other reagents used for these tests were of analytical grade.

Experimental animal: Swiss Albino mice of both sexes (4-5 weeks old) weighing between 25-35 gm were obtained from the Department of Pharmacy, Jahangir Nagar University. The mice were kept in the animal house of the State University of Bangladesh and fed with standard rodent feed. As these animals are sensitive towards environmental change, they were kept for 4 days in the laboratory environment prior to experimental use. The Federation of European Laboratory Animal Science Associations (FELASA) guidelines and recommendations were followed to reduce the pain and stress of the experimental mice. In case of in-vivo analysis, 12 Swiss Albino mice were randomly divided into four groups (i.e., positive control, negative control and two test groups receiving methanolic extract at doses of 200 and $400 \mathrm{mg} / \mathrm{kg}$ of body weight). 
Determination of total phenolic content: The total phenolic content of the whole plant of $G$. tiliaefolia was determined by following reported protocol (Skerget et al., 2005) using Folin-Ciocalteu reagent (i.e., a mixture of phosphomolybdate and phosphotungstate) as oxidizing agent and gallic acid as standard.

Antioxidant activity (DPPH assay): The free radical scavenging activities (antioxidant capacity) of the plant extractives on the stable radical 1,1diphenyl-2-picrylhydrazyl (DPPH) were estimated by the method of Brand-Williams et al., 1995).

Cytotoxic activity (Brine shrimp lethality bioassay): Brineshrimp lethality bioassay was performed using the procedures reported by Meyer and co-workers (Meyer et al., 1982).

Anti-inflammatory activity (membrane stabilizing bioassay): According to the method developed by Shinde and co-workers (Shinde et al., 1999) and further modified by Sikder and co-workers (Sikder et al., 2011), the membrane stabilizing activity of the extractives was determined by evaluating their ability to prevent hypotonic solution and heatinduced hemolysis of human erythrocyte.

Thrombolytic activity: In order to find the thrombolytic ability (i.e., determining percentage clot lysis) of extractives, the method used by Prasad and co-workers (Prasad et al., 2006) was employed in this study. Here, $10 \mathrm{ml}$ blood sample were collected and distributed equally into pre-weighed sterile vial $(1 \mathrm{ml} / \mathrm{vial})$ and incubated at $37^{\circ} \mathrm{C}$ for 45 minutes. After clot formation, the serum was completely removed, and $100 \mu \mathrm{l}$ aqueous solutions of different partitions along with the crude extracts were added separately. As a negative control, 100 $\mu 1$ of distilled water was added to the control vial, while streptokinase was used as the standard. All the vials were incubated at $37^{\circ} \mathrm{C}$ for 90 minutes and observed for clotlysis using the formula:

$$
\text { Percentage clot lysis }=\frac{\text { Weight of the lysed clot }}{\text { Weight of clot before lysis }} \times 100
$$

Antimicrobial activity: The extract and its distinctive portions were assessed by single disk diffusion technique (Murray et al., 1995; Zavala et al., 1997) to decide their antimicrobial potencies at $400 \mu \mathrm{g} / \mathrm{disc}$. In this examination, ciprofloxacin and fluconazole $(30 \mu \mathrm{g} / \mathrm{disc})$ circles were utilized as the reference for the antibacterial and antifungal screening.

Central and peripheral analgesic activity: The tail flicking test (Pizziketti et al., 1985) and acetic acid induced writhing test (Kaushik et al., 2012) were followed to determine the central and peripheral analgesic activity, respectively. In both cases, the mice were divided into four groups (3 mice in each group), positive control, negative control, methanol extract receiving groups (200 and $400 \mathrm{mg} / \mathrm{kg}$-body weight). In the tail flicking method, two doses were fed orally to the mice and the tips of their tails were immersed in hot water at 15 second interval and the time taken to respond was recorded at 30, 60 and 90 minutes interval. Morphine (2 $\mathrm{mg} / \mathrm{kg}$-body weight) was injected subcutaneously to the positive control group and 1\% Tween-80 in saline mixture $(0.1 \mathrm{ml} / 10 \mathrm{mg})$ was fed to the negative control group. The pain inhibition process (PIP) was calculated using the following formula:

Pain inhibition percentage (PIP) $=\left[\frac{T_{1}-T_{0}}{T_{0}}\right] \times 100$

where, $\mathrm{T}_{1}=$ post - drug latency; $\mathrm{T}_{0}=$ pre-drug latency

For the writhing method, the positive control group received diclofenac sodium $(50 \mathrm{mg} / \mathrm{kg}$-body weight) orally while the negative control group received distilled water $(10 \mathrm{ml} / \mathrm{kg})$. Two doses $(200$ and $400 \mathrm{mg} / \mathrm{kg}$-body weight) of crude extract were fed orally and waited for 40 minutes before injecting $1 \%(\mathrm{v} / \mathrm{v})$ of acetic acid at a dose of $10 \mathrm{ml} / \mathrm{kg}$-body weight, intra-peritonially. The acetic acid induced writhing movement in the mouse and the time taken for licking response was recorded. Percent inhibition 
of writhing movement was proportional to the analgesic activity and was calculated using the formula as shown below:

Percentage inhibition $=\frac{\text { Response time in negative control }- \text { Response time in test group }}{\text { Response time in negative control }}$

Hypoglycemic activity assay: Tail tipping method was used to determine the hypoglycemic effect of the test samples in mice (Dürschlag et al., 1996). In the study, blood was withdrawn from the tip of the tail and the sugar level was measured by using glucometer. A total of twelve mice divided into four groups were used in this study. The mice of negative and positive control groups received $1 \%$ Tween-80 in saline $(0.1 \mathrm{ml} / 10 \quad \mathrm{mg})$ and glibenclamide ( $5 \mathrm{mg} / \mathrm{kg}$-body weight), respectively. The methanol extract (at 200 and $400 \mathrm{mg} / \mathrm{kg}$-body weight of dose) partition was given orally to mice of treatment groups. After 60 minutes, $10 \%$ glucose solution ( $2 \mathrm{~g} / \mathrm{kg}$-body weight) was given orally to all the mice. The blood sugar level was again recorded after 1st, 2nd and 3rd hour of administration of glucose solution.

Anti-diarrheal activity assay: Mice of both sexes were fasted for $18 \mathrm{hrs}$. The selected mice for castor oil-induced diarrheal test were divided into six groups (where, $n=3$ ). Group-I (control group) was given normal saline ( $2 \mathrm{ml} / \mathrm{kg}$-body weight) orally and group-II (standard group) received loperamide (2 $\mathrm{mg} / \mathrm{kg}$-body weight), groups-III and IV received methanol extract of G. tiliaefolia at doses of 200 and $400 \mathrm{mg} / \mathrm{kg}$-body weight. After 60 minutes, each mouse of four groups received castor oil $(1 \mathrm{ml})$ orally. Later, they were placed in cages lined with adsorbent papers and observed for 4 hrs for the presence of characteristic diarrheal droppings.

\section{Results and Discussion}

The crude extract of $G$. tiliaefolia and its Kupchan partitionates were analyzed for in-vitro bioactivities, while the methanol extract at 200 and $400 \mathrm{mg} / \mathrm{kg}$-body weight were used for the in-vivo bioassays.
The highest phenolic content was obtained in PESF $(78.30 \pm 1.60 \mathrm{mg}$ of $\mathrm{GAE} / \mathrm{g}$ ), followed by the methanol extract $(70.37 \pm 0.84 \mathrm{mg})$ and chloroform soluble fractions $(48.52 \pm 1.16 \mathrm{mg})$. This high phenolic content could be an indication for the presence of different phyto-constituents such as flavonoids and tannins, which are well known for their antioxidant activity (Akinmoladun et al., 2007; Pietta et al., 2000; Hagerman et al., 1999).

Similar trends were also observed in case of evaluating the free radical scavenging potential, cytotoxic efficacy and thrombolytic activity. In all the cases, the PESF gave better activity compared to the ME and CSF. The $\mathrm{IC}_{50}$ values for free radical scavenging activity test were found as $24.79 \pm 0.17$, $28.88 \pm 0.02$ and $37.51 \pm 0.96 \mu \mathrm{g} / \mathrm{ml}$, in case of PESF, ME and CSF, respectively (Table 1). The significant high levels of free radical scavenging and cytotoxic activities of $G$. tiliaefolia test samples could be attributed to the presence of these phenolics and flavonoid contents.

In this case, the $\mathrm{IC}_{50}$ of PESF and $\mathrm{ME}$ were comparable to the standard BHT (25.18 \pm 1.89 $\mu \mathrm{g} / \mathrm{ml})$. In case of cytotoxic activity, the PESF showed the highest cytotoxic activity with $\mathrm{LC}_{50}$ value of $2.59 \pm 0.14 \mu \mathrm{g} / \mathrm{ml}$ followed by methanol extract with $\mathrm{LC}_{50}$ value of $3.38 \pm 0.08 \mu \mathrm{g} / \mathrm{ml}$ as compared to the standard vincristine sulfate $\left(\mathrm{LC}_{50}=\right.$ $0.45 \pm 0.00 \mu \mathrm{g} / \mathrm{ml}$ ) (Table 1 ). The highest capacity to lyse blood clot was also shown by the PESF $(46.45 \pm 0.23 \%)$ and ME (30.30 $\pm 0.08 \%)$. These results were also comparable to the standard streptokinase $(67.36 \pm 0.19 \%)$ (Table 1).

During the evaluation of membrane stabilizing activity using hypotonic solution induced hemolysis, all the fractions of G. tiliaefolia showed satisfactory inhibition; but, the percent inhibitory effects for all 
fractions were lower than the standard acetyl salicylic acid $(85.37 \pm 3.00 \%)$. Highest percentage of inhibition of hemolysis was exhibited by the PESF $(69.18 \pm 0.54 \%)$ followed by the ME $(58.05 \pm 1.32 \%)$ (Table 1).

During the inhibition of heat induced hemolysis, PESF, DCMSF and ME revealed the inhibitory effect close to the standard acetyl salicylic acid $(42.11 \pm 0.10 \%)$ (Table 1$)$. The observations in thrombolytic assay may also have significance since it may lead to the discovery of new cardiovascular drugs (Hussain et al., 2014). The highest thrombolytic and membrane stabilizing activity (hypotonic, heat induced) were shown by the $\mathrm{PE}$ and $\mathrm{ME}$ of G.tiliaefolia. Even though, in both the cases the results were lower but promising when compared to the standards.

However, further study in order to isolate the compound(s) responsible could result in the discovery of better anti-coagulating agents.

The methanol extract of $G$. tiliaefolia showed a dose dependent inhibition of castor oil-induced diarrhea in Swiss albino mice. The methanol extract when given at 200 and $400 \mathrm{mg} / \mathrm{kg}$-body weight reduced diarrhea by $39.29 \%(\mathrm{p}<0.01)$ and $71.43 \%(\mathrm{p}$ $<0.001$ ), respectively (Table 2 ).

Table 1. Total phenolic content, antioxidant and cytotoxic activity of test samples of G.tiliaefolia.

\begin{tabular}{|c|c|c|c|c|c|c|}
\hline \multirow{2}{*}{$\begin{array}{l}\text { Samples/ } \\
\text { Standards }\end{array}$} & \multirow{2}{*}{$\begin{array}{c}\text { Total phenolic } \\
\text { content } \\
\text { (mg of GAE/g } \\
\text { of dried extract) }\end{array}$} & \multirow{2}{*}{$\begin{array}{l}\text { Anti-oxidant } \\
\text { activity } \\
\mathrm{IC}_{50}(\mu \mathrm{g} / \mathrm{ml})\end{array}$} & \multirow{2}{*}{$\begin{array}{l}\text { Cytotoxic } \\
\text { activity } \\
\mathrm{LC}_{50} \\
(\mu \mathrm{g} / \mathrm{ml})\end{array}$} & \multirow{2}{*}{$\begin{array}{c}\text { Thrombolytic } \\
\text { activity } \\
\text { (\% of clot } \\
\text { lysis) }\end{array}$} & \multicolumn{2}{|c|}{ Membrane stabilizing activity } \\
\hline & & & & & $\begin{array}{l}\% \text { Inhibition of } \\
\text { hypotonic } \\
\text { solution induced } \\
\text { hemolysis }\end{array}$ & $\begin{array}{c}\% \text { Inhibition o } \\
\text { heat } \\
\text { induced } \\
\text { hemolysis }\end{array}$ \\
\hline ME & $70.37 \pm 0.84$ & $28.88 \pm 0.02$ & $3.38 \pm 0.08$ & $30.30 \pm 0.08$ & $58.05 \pm 1.32$ & $32.85 \pm 0.56$ \\
\hline PESF & $78.30 \pm 1.60$ & $24.79 \pm 0.17$ & $2.59 \pm 0.14$ & $46.45 \pm 0.23$ & $69.18 \pm 0.54$ & $39.70 \pm 0.22$ \\
\hline DCMSF & $10.12 \pm 0.55$ & $164.40 \pm 27.17$ & $255.54 \pm 0.45$ & $10.93 \pm 0.01$ & $54.21 \pm 0.78$ & $36.60 \pm 0.92$ \\
\hline $\mathrm{CSF}$ & $48.52 \pm 1.16$ & $37.51 \pm 0.96$ & $73.55 \pm 0.26$ & $24.72 \pm 0.01$ & $54.72 \pm 0.45$ & $21.85 \pm 0.07$ \\
\hline AQSF & $38.58 \pm 0.77$ & $39.01 \pm 0.84$ & $139.74 \pm 0.77$ & $11.63 \pm 0.02$ & $54.20 \pm 2.55$ & $26.79 \pm 1.37$ \\
\hline VS (std.) & - & - & $0.45 \pm 0.00$ & - & - & - \\
\hline BHT (std.) & - & $25.18 \pm 1.89$ & - & - & - & - \\
\hline ASA (std.) & - & - & - & - & $85.37 \pm 3.00$ & $42.11 \pm 0.10$ \\
\hline SK (std.) & - & - & - & $67.36 \pm 0.19$ & - & - \\
\hline
\end{tabular}

$\mathrm{ME}=$ Methanol extract $\mathrm{PESF}=$ Pet ether soluble fraction; $\mathrm{DCMSF}=$ Dichloromethane soluble fraction; $\mathrm{CSF}=\mathrm{Chloroform}$ soluble fraction; $\mathrm{AQSF}=$ Aqueous soluble fraction; VS = Vincristine sulfate; $\mathrm{BHT}=$ Butylated hydroxyl toluene; GAE = Gallic acid equivalent, $\mathrm{ASA}=$ Acetyl salicylic acid; $\mathrm{SK}=$ Streptokinase

Table 2. Antidiarrheal activity of crude methanol extract of G. tiliaefolia.

\begin{tabular}{lccc}
\hline Test groups & $\begin{array}{c}\text { No. of } \\
\text { mice }\end{array}$ & $\begin{array}{c}\text { Number of diarrheal feces } \\
\text { Mean } \pm \text { SEM }\end{array}$ & $\begin{array}{c}\text { \% Reduction of } \\
\text { diarrheal feces }\end{array}$ \\
\hline $\begin{array}{l}\text { Control } \\
(1 \% \text { Tween-80) }\end{array}$ & 3 & $9.33 \pm 0.24$ & - \\
$\begin{array}{l}\text { Loperamide (standard) } \\
(2 \mathrm{mg} / \mathrm{kg} \text {-body weight })\end{array}$ & 3 & $3.33 \pm 0.24$ & 64.29 \\
ME (200 mg/kg- body weight) & 3 & & 39.29 \\
ME (400 m mg/kg- body weight) & 3 & $5.67 \pm 0.47$ & 71.43 \\
\hline
\end{tabular}

Here, $n=3$; Values are expressed as mean \pm SEM; $\mathrm{p}<0.05$ significant when compared to negative control. 
The methanol extract of G. tiliaefolia was found to lower the blood sugar level significantly ( $\mathrm{p}<$ 0.001) during evaluating its hypoglycemic activity by tail tipping method. Its efficacy was evident even after 3rd hour of administration of the glucose solution.

The blood sugar level was reduced by $66.17 \%$ $(\mathrm{p}<0.001)$ and $71.42 \%(\mathrm{p}<0.001)$ at 200 and 400 $\mathrm{mg} / \mathrm{kg}$-body weight of doses, respectively (Table 3 ).

In case of central analgesic activity assay by tail-flick method, $105.95 \%(\mathrm{p}<0.01)$ and $165.07 \%$ $(\mathrm{p}<0.001)$ elongation of the reaction time was observed after 30 and 60 minute of administration of ME (200 mg/kg-body weight), respectively. The methanol extract at $400 \mathrm{mg} / \mathrm{kg}$-body weight showed $129.73 \%(\mathrm{p}<0.01)$ and $190.83 \%(\mathrm{p}<0.001)$ of pain inhibition at the same time period (Table 4).

On the other hand, in case of acetic acid induced writhing assay, the crude extract of G. tiliaefolia in hibited the number of writhing by $54.17 \%$ ( $\mathrm{p}<0.01$ ) and $64.58 \%(\mathrm{p}<0.001)$ at two different doses, which were lower but significant when compared to the $77.08 \%$ inhibition by the standard diclofenac sodium (Table 5).

Table 3. Antidiabetic activity of methanol extract of G. tiliaefolia.

\begin{tabular}{|c|c|c|c|c|c|c|c|}
\hline \multirow{3}{*}{ Test groups } & \multicolumn{5}{|c|}{ Average blood glucose level (mmol/l) } & \multicolumn{2}{|c|}{$\begin{array}{c}\% \text { Reduction of glucose } \\
\text { level }\end{array}$} \\
\hline & \multirow{2}{*}{$\begin{array}{c}\text { Before } \\
\text { treatment }\end{array}$} & \multicolumn{4}{|c|}{ After treatment (minute) } & \multirow[b]{2}{*}{$120 \mathrm{~min}$} & \multirow[b]{2}{*}{$180 \mathrm{~min}$} \\
\hline & & 30 & 60 & 120 & 180 & & \\
\hline $\begin{array}{l}\text { Control } \\
(1 \% \text { Tween-80) }\end{array}$ & $4.80 \pm 0.78$ & $14.1 \pm 4.23$ & $17.17 \pm 0.62$ & $15.67 \pm 1.69$ & $14.13 \pm 0.85$ & - & - \\
\hline $\begin{array}{l}\text { Glibenclamide } \\
(5 \mathrm{mg} / \mathrm{kg} \mathrm{bw})\end{array}$ & $5.67 \pm 0.81$ & $16.63 \pm 2.41$ & $5.23 \pm 1.03$ & $4.17 \pm 1.43$ & $3.47 \pm 0.83$ & 70.43 & 75.39 \\
\hline ME (200 mg/kg bw) & $4.17 \pm 0.23$ & $13.8 \pm 3.1$ & $6.17 \pm 0.64$ & $4.27 \pm 0.52$ & $4.77 \pm 1.67$ & 69.72 & 66.17 \\
\hline ME (400 mg/kg bw) & $3.47 \pm 0.07$ & $15.3 \pm 1.31$ & $9.23 \pm 4.69$ & $4.8 \pm 1.83$ & $4.03 \pm 0.65$ & 65.96 & 71.42 \\
\hline
\end{tabular}

Here, $\mathrm{n}=3$; Values are expressed as mean \pm SEM; $\mathrm{p}<0.05$ significant when compared to negative control.

Table 4. Central analgesic activity of crude methanol extract of G. tiliaefolia.

\begin{tabular}{|c|c|c|c|c|c|c|c|}
\hline \multirow{2}{*}{ Test groups } & \multicolumn{4}{|c|}{ Mean of tail immersion time (minute) \pm SEM } & \multicolumn{3}{|c|}{$\%$ Elongation of response } \\
\hline & 0 & 30 & 60 & 90 & $0 \mathrm{~min}$ & $30 \mathrm{~min}$ & $60 \mathrm{~min}$ \\
\hline $\begin{array}{l}\text { Control } \\
\text { (1\% Tween-80) }\end{array}$ & $1.69 \pm 0.08$ & $1.85 \pm 0.19$ & $2.29 \pm 0.14$ & $2.14 \pm 0.14$ & - & - & - \\
\hline $\begin{array}{l}\text { Morphine } \\
(2 \mathrm{mg} / \mathrm{kg})\end{array}$ & $1.75 \pm 0.10$ & $5.68 \pm 0.07$ & $9.05 \pm 0.15$ & $12.98 \pm 0.14$ & 3.55 & 207.03 & 295.20 \\
\hline $\begin{array}{l}\text { ME } \\
(200 \mathrm{mg} / \mathrm{kg})\end{array}$ & $1.99 \pm 0.06$ & $3.81 \pm 0.21$ & $6.07 \pm 0.23$ & $7.61 \pm 0.20$ & 17.75 & 105.95 & 165.07 \\
\hline $\begin{array}{l}\text { ME } \\
(400 \mathrm{mg} / \mathrm{kg})\end{array}$ & $1.98 \pm 0.04$ & $4.25 \pm 0.36$ & $6.66 \pm 0.30$ & $9.41 \pm 0.29$ & 17.16 & 129.73 & 190.83 \\
\hline
\end{tabular}

Values are expressed as mean \pm SEM $(n=3) ; \mathrm{p}<0.05$ significant when compared to negative control. 
Table 5. Peripheral analgesic activity of crude methanol extract of G. tiliaefolia.

\begin{tabular}{|c|c|c|c|c|c|c|}
\hline \multirow{2}{*}{ Test groups } & \multicolumn{3}{|c|}{ Writhing count } & \multirow{2}{*}{$\begin{array}{l}\text { Number of writhing } \\
\text { Mean } \pm \text { SEM }\end{array}$} & \multirow{2}{*}{$\%$ Writhing } & \multirow{2}{*}{$\begin{array}{l}\% \text { Inhibition of } \\
\text { writhing }\end{array}$} \\
\hline & M1 & M2 & M3 & & & \\
\hline $\begin{array}{l}\text { Control } \\
\text { (1\% Tween-80) }\end{array}$ & 17 & 17 & 14 & $16.00 \pm 1.00$ & 100 & - \\
\hline $\begin{array}{l}\text { Diclofenac sodium } \\
(50 \mathrm{mg} / \mathrm{kg} \mathrm{bw})\end{array}$ & 4 & 5 & 2 & $3.67 \pm 0.88$ & 22.98 & 77.08 \\
\hline ME (200 mg/kg bw) & 9 & 7 & 6 & $7.33 \pm 0.88$ & 45.81 & 54.17 \\
\hline ME (400 mg/kg bw) & 6 & 5 & 6 & $5.67 \pm 0.33$ & 35.44 & 64.58 \\
\hline
\end{tabular}

Values are expressed as mean \pm SEM $(n=3) ; p<0.05$ significant when compared to negative control.

\section{Conclusion}

This preliminary in vitro and in vivo bioassays with the crude extract and different organic partitions of G. tiliaefolia provides evidence that the plant possess potential biologically active chemical constituents responsible for its various medicinal properties. However, further study needs to be carried out in order to isolate and purify the compounds responsible for such pharmacological activities. Determination of the structure and analyzing the structure activity relationship could lead to discovery of potential drug candidates.

\section{References}

Akinmoladun, A.C., Ibukun, E.O., Afor, E., Akinrinlola, B.L., Onibon, T.R., Akinboboye, A.O., Obuotor, E.M. and Farombi, E.O. 2007. Chemical constituents and antioxidant activity of Alstonia boonei. Afr. J. Biotechnol. 6.1197-1201.

Bauer, A.W., Kirby, W.M.M., Sherris, J.C. and Turck, M. 1966. Antibiotic susceptibility testing by a standardized single disk method. Am. J. Clin. Pathol. 45, 493-496.

Brand-Williams, W., Cuvelier, M.E. and Berset, C. 1995. Use of a free radical method to evaluate antioxidant activity. LWT-Food Sci. Technol. 28, 25-30.

Carag, H. and Buot Jr, I. 2017. A checklist of the orders and families of medicinal plants in the Philippines. Sylvatrop: The Tech. J. Philippines Ecosyst. Nat. Resour. 27, 49-59.
Dürschlag, M., Würbel, H., Stauffacher, M. and Von Holst, D. 1996. Repeated blood collection in the laboratory mouse by tail incision-modification of an old technique. Physiol. Behav. 60, 1565-1568.

Firenzuoli, F. and Gori, L. 2007. Herbal medicine today: clinical and research issues. J. Evid. Based. Complemen. Altern. Med. 4, 37-40.

Firenzuoli, F., Gori, L., Crupi, A. and Neri, D. 2004. Flavonoids: risks or therapeutic opportunities? Recent. Prog. Med. 95, 345-351.

Hagerman, A.E., Riedl, K.M. and Rice, R.E. 1999. Tannins as biological antioxidants. In: Plant Polyphenols 2 (Gross G.G., Hemingway R.W., Yoshida T. and Branham S.J., Eds). Basic Life Sciences, 66. Springer, Boston, M.A. pp. 495-505.

Hussain, F., Islam, A., Bulbul, L., Moghal, M.R. and Hossain, M.S. 2014. In-vitro thrombolytic potential of root extracts of four medicinal plants available in Bangladesh. Anc. Sci. Life. 33, 162-164.

Kadir, M.F., Sayeed, M.S.B. and Mia, M.M.K. 2013. Ethnopharmacological survey of medicinal plants used by traditional healers in Bangladesh for gastrointestinal disorders. J. Ethnopharmacol. 147, 148-156.

Kaushik, D., Kumar, A., Kaushik, P. and Rana, A.C. 2012. Analgesic and anti-inflammatory activity of Pinus roxburghii Sarg. Adv. Pharmacol. Sci. 2012.

Khatun, A., Khan, M.A.A., Rahman, M.A., Akter, M.S., Hasan, A., Parvin, W., Ripa, R.J., Moniruzzaman, M., Mahal, M.J. and Rahmatullah, M. 2013. Ethnomedicinal usage of plants and animals by folk medicinal practitioners of three villages in Chuadanga and Jhenaidah districts, Bangladesh. Am-Eur. J. Sustain. Agr. 7, 319-339. 
Meyer, B.N., Ferrigni, N.R., Putnam, J.E., Jacobsen, L.B., Nichols, D.J. and McLaughlin, J.L. 1982. Brine shrimp: a convenient general bioassay for active plant constituents. Planta Med. 45, 31-34.

Moniruzzaman, M., Kuddus, M.R., Haque, M.R., Chowdhury, A.S. and Rashid, M.A. 2018. Stereospermum suaveolens (Roxb.) DC. shows potential in vivo and in vitro bioactivities. Dhaka Univ. J. Pharm. Sci. 17, 257-263.

Motaleb, M.A., Abdullah-Al-Mamun, M.M., Hossain, M.K., Alam, M.K. and Sultana, M. 2015. Herbal healing: an old practice for healthy living among Khumi, Marma and Tripura communities of Thanchiupazila, Bangladesh. European J. Med. Plants. 5, 23-52.

Murray, P.R., Baron, E.J., Pfaller, M.A., Tenover, F.C. andYolken, R.H. 1995. Manual of Clinical Microbiology, 6th edition. American Society of Microbiology Press, Washington DC. p. 1482.

Pietta, P.G. 2000. Flavonoids as antioxidants. J. Nat. Prod. 63, 1035-1042.

Pizziketti, R.J., Pressman, N.S., Geller, E.B., Cowan, A. and Adler, M.W. 1985. Rat cold water tail-flick: a novel analgesic test that distinguishes opioid agonists from mixed agonist-antagonists. Eur. J. Pharmacol. 119, 23-29.

Prasad, S., Kashyap, R.S., Deopujari, J.Y., Purohit, H.J., Taori, G.M. and Daginawala, H.F. 2007. Effect of Fagoniaarabica (Dhamasa) on in vitro thrombolysis. BMC Complement Altern Med.7, 36.

Sikder, A.A., Rahman, M.A., Kaisar, M.A.,Rahman, M.S., Hasan, C.M. and Rashid, M.A., 2011. In vitro antioxidant, reducing power, free radical scavenging and membrane stabilizing activities of seeds of Syzygium cumini L. Lat. Am. J. Pharm. 30, 781-785
Sarwar, A.G. 2015. Medicinal plant genetic resources of Bangladesh-genera represented by single species and their conservation needs. J. Med. Plants Studies. 3, 65-74.

Sharma, A., Shanker, C., Tyagi, L.K., Singh, M. and Rao, C.V. 2008. Herbal medicine for market potential in India: an overview. Acad. J. Plant Sci. 1, 26-36.

Shinde, U.A., Phadke, A.S., Nair, A.M., Mungantiwar, A.A., Dikshit, V.J. and Saraf, M.N. 1999. Membrane stabilizing activity - apossible mechanism of action for the anti-inflammatory activity of Cedrus deodara wood oil. Fitoterapia. 70, 251-257.

Škerget, M., Kotnik, P., Hadolin, M., Hraš, A.R., Simonič, M. and Knez, Ž. 2005. Phenols, proanthocyanidins, flavones and flavonols in some plant materials and their antioxidant activities. Food Chem. 89, 191-198.

Twarog, S. and Kapoor, P. 2004. Protecting and promoting traditional knowledge: systems, national experiences and international dimensions. United Nations Conference on Trade and Development. United Nations Publication. Geneva, Switzerland.

VanWagenen, B.C., Larsen, R., Cardellina, J.H., Randazzo, D., Lidert, Z.C. and Swithenbank, C. 1993. Ulosantoin, a potent insecticide from the sponge Ulosa ruetzleri. J. Org. Chem. 58, 335-337.

Williamson, E.M., Okpako, D.T. and Evans, F.J. 1996. In: Selection, Preparation and Pharmacological Evaluation of Plant Material (Vol. 1). John Wiley \& Sons.

Zavala, S.M.A., Perez, G.S. and Perez, G.R.M. 1997. Antimicrobial screening of some medicinal plants. Phytother. Res. 11, 368. 